\title{
The Number of Years in Displacement and Gender as Mediating Factors of the Relation Between Ways of Confronting Psychological Stresses and Psychological Hardiness
}

\author{
Dr. Ola Darab Nasser, Assistant Professor \\ Department of Psychological Counseling, \\ Faculty of Education II in Sweida, Damascus University, Syria
}

Doi:10.19044/esj.2019.v15n25p239 URL:http://dx.doi.org/10.19044/esj.2019.v15n25p239

\begin{abstract}
This study employs the descriptive approach to identify the relationship between the ways of confronting stress and the psychological hardiness in displaced adolescents according to various variables. The main sample was selected randomly from the original study population. The sample consisted of (200) displaced adolescents (99 males and 101 females) from Sweida secondary schools. Two types of test instruments were used: The Psychological Hardiness Scale by (Nasser, 2012) and the Ways of Confronting Stresses Scale by (Al Abdallah, 2014). The psychometric properties of both scales were tested. To answer the study questions, the following statistics were used: Pearson correlation coefficient, t-test, one-way ANOVA Test, LSD test. The results indicate a positive correlation between the ways of confronting stresses and psychological hardiness. There was no significant difference between female and male students in terms of psychological hardiness, and neither was there any significant difference in Psychological hardiness according to age. The study also indicates differences between males and females in terms of denial. It seems that females are more denial than males and there are differences in the style of planning to solve problems according to age differences. The category ( 5 years and above) a higher degree of the planning to solve problems. The results of this research is likely to be a starting point for designing of the activities and training courses. Researchers should focus on the importance of psychological hardiness development programs as well as mental health practitioners should focus on the planning of integrated rehabilitation programs, furthermore they should pay more attention to social support, family unity, workshops and training courses for displaced adolescents.
\end{abstract}

Keywords: Confronting, Psychological stresses, Hardiness, Displaced 


\section{Introduction}

In our daily lives, we face many experiences, notwithstanding the stressful life events and burdens. Some people can overcome these obstacles and continue their lives normally. Hans Selye (1956) is considered to be one of the first persons to discuss psychological stress. More so he was the first to introduce the term "stress". While Zimbardo (1969) definition is: "Pattern of specific and non-specific responses carried out by a living being as a result of dramatic events that hindered its life balance, and the frustrations in attempts to confront them, these inciting events include many different internal and external factors"

From sudden or tough stress which can affect many people at once in many nations, natural disasters, and wars (Al Abdali, 2012). The most painful impact of wars with their tragedies are forced migration and displacement under the pressure of fear and terror, which leaves negative effects on the individual's personality. Thousands of people are forced to flee, leaving their homes to escape the war, persecution and starvation in an attempt to save their lives.

Internally displaced persons (International Law Series No. 8, 2008) are described by the United Nations High Commissioner for Refugees (UNHCR, 2006) as: "Persons or groups who have been forced to flee or leave their homes or places of habitual residence as a result of armed conflict. The internal strife, and habitual violations of human rights, as well as natural or man-made disasters involving one or more of these elements, and who have not crossed an internationally recognized state border".

The Psychological and social effects create an impact of daily pressures of displacement as dislodgment increases because of poverty, lack of basic needs and services. Others include risks of violence, exploitation, isolation, loss of family and community support and the uncertain future. The most affected victims are adolescents who are going through a critical developmental age, which already have a lot of conflicts, needs, self-discovery and finding the identity. However, these things weigh heavily on the adolescent especially when he/she is suffering from internal displacement, which will create new stress to deal with and to confront in multiple ways. These confrontations differ from one person to another.

Ways of confronting stresses defines best as a group of activities, procedures, behaviors and knowledge through which the individual seeks to adapt with the current situation to solve the problems, or to reduce the resulting emotional stress and trying to manage their stressful situations in some effective ways (Khalil \& Abdullah, 2013). Some of these ways are logical analysis, problem-solving planning, avoidance, denial, positive thinking, returning to religion, seeking social support and expressing their feelings. The results of these studies showed that the most common ways of confronting 
psychological stresses are, active management, planning and resorting to religion and re-evaluation of positive planning problem-solving, reevaluation, logical analysis, social support, and confrontation. (Arafi, 2014); (Abbass, 2006).

Furthermore, the attention have been increased to develop the strategies to deal with psychological stress focusing on personal and environmental variables that would help the individual in the self-protection from the psychological and physical impacts resulting from exposure to stresses (Al Abdalla, 2014). Especially psychological hardiness, which is a relatively modern concept in psychology that appeared in the late seventies of the last century, which was first introduced by Suzanne Kobasa with Salvatore Maddi (1977,1979). Through studies that discussed the psychological and social variables that help people maintain their physical and psychological health despite being under pressure. In a particular way, many individuals confront these pressures in different ways ranging from flexibility and effectiveness to inflexibility, negativity and illness (Kobasa,1982); (Kafa, 2012).

Kobasa also described the concept of psychological hardiness as a general belief of the individual in his ability and effectiveness to use all available psychosocial resources and be able to understand, explain and effectively cope with stressful life events. (A resistance resource in the encounter with stressful situations). A person has three general characteristics: A; Faith in controlling and affecting events. B; The ability to feel deeply and with commitment about individual activities. $\mathrm{C}$; Expecting that a change along with existing challenges is more effective for growth and consider it as an usual aspect of life (Kobasa,1982).

Psychological hardiness consists of three dimensions:

1. Commitment: Commitment refers to the high tendency to involve oneself in different life activities and social relationships. Moreover, it is the tendency to participate and engage in work and confront problems successfully. Commitment reflects a expression as an individual tendency to be more powerful and active towards its environment for participating positively in life events, and to be away from isolation, passive, idle and laziness 15

2. Control or containment: Means the convictions of internal control of the human, it is the human experience that gives him a definite or clear influence on the events of his life. Control also includes the ability to make decisions, to choose between alternatives, ability to interpret and evaluate life events and the effective response to stresses. As a result, control is the ability of the individual to predict difficult situations based on his interpretation of reality, and to develop appropriate plans to confront them and reduce their impacts when they do occur. 
3. Challenge: It is a "challenge versus sense of threat", desire to change and cope with serious activities which represent or with give opportunities for personal growth and development. The third dimension is the challenge disposition. The central belief is that stability is unusual and that change is to be expected. Changes are seen as opportunities for growth or interesting incentives rather than crises or threats. These individuals value openness and flexibility.

Many studies have addressed psychological hardiness and ways of effectively confronting psychological stress. We conclude that ways of confronting pychological stress in general is significantly related to psychological hardiness. (Al Abdali, 2012); (International Law Series No. 8, 2008); (Reinhoudt \& Cynthia, 2004); (Soderstrom, 2000). Furthermore, psychological hardiness also have positive effects on reducing daily stress. There is also a relationship between psychological hardiness and self-esteem and social support (Ghalyanee, 2016); (Jindal, 2013). Psychological hardiness can affect oneself indirectly with the mediation of social supports and selfesteem (Hashemi \& Yekta, 2017). While a study (Auten, 1990) found no relationship between ego strength or psychological hardiness and planning to solve problems. A study (Awali, 2016) found that there is a negative relationship between psychological hardiness and stress perception.

Moreover, studies that have investigated gender variables are contradictory; Some studies have found differences between males and females in psychological hardiness, these differences are in favor of females (Yaprak ,Güçlü, Durhan, 2018). While others have found differences in favor of males (Shalhoub, 2016). In addition to other studies that had no differences at all between males and females (Nasser, 2012) : (Al Mishaan, 2011).

With regard to ways of confronting psychological stresses, there was a study which showed differences between males and females (Soderstrom, 2000), indicated that females used greater avoidance coping strategies, and indicated that females used greater positive reinterpretation and growth coping strategies than males. In addition, females used greater focus and venting of emotions coping strategies and reinterpretation while males are more used to strategies of cognitive withdrawal, acceptance and denial. While other studies had differences in favor of males. Indicated that males used greater positive reinterpretation strategies, Problem-solving, while female are more frequently used to strategies for cognitive withdrawal and denial (Abbass, 2006); (Al Zayoud, 2014).

Finally, The need for this study is based on the contradictory results of previous studies, and based on researcher field vision and his faith in working on psychological aspect of displaced adolescents. 


\section{Study Issues and Questions:}

Psychological stress is a natural response to physical or emotional challenges. It occurs when the balance between life's demands and adaptation resources are lost. On one hand, stress represents challenges that distinguish us, and make us alert. More so, psychological stress represents situations in which individuals are unable to response to their life demands. Ultimately, they eventual suffer from physical and mental breakdown (Fedman, 2010). Psychological stress may sometimes be a positive motivated driving force and a source of vitality and activity that helps the individual to achieve his goals by redoubling his efforts and activities with the life demands which must include a certain amount of pressures (Mohammed, 2017). Lazarus (1966) confirmed in his study, that individuals are not merely victims of stress, however they are also victims of how they value their life together with stressful events and the way they use their own resources in dealing with those events. From this point, the researchers began focusing on the variables that protect the individual from the harmful impacts of stressful events and support its ability to cope with these stresses (Al Sherbini, 2005). Michael and Rutter (1990) pointed out that the protective variables of stresses impact (personal and social variables), with could reduce the impact of stress with on cognitive, emotional and social aspects of individual for his/ her effectiveness. Such as psychological hardiness (Radi, 2008).

The Psychological hardiness, internal resources and personality traits are reducing the negative effects of stressful life events on physical and mental health (Yaprak, 2018). It is personal qualities that helps the individuals to cope with their life stresses and to act positively, by using effective confronting ways. Ways which defend and protect the individual falling into mental and physical disease clutches, resulting from exposure to those stresses, problems and obstacles. The study of (Soderstrom, 2000) confirms the relation between psychological stress confronting strategies and psychological hardiness. That relation plays an important role helping the individual to cope with, and challenge the stresses and turn these stresses into a new opportunity to learn. Moreover, that relation increases individual stamina and improves his skills of dealing with people and current events around him instead of feeling isolated, and as a result, it leads to achieve mental health. Therefore, the ways of confronting psychological stresses are connected with the general attitude of the individual towards the environment in which he works, he tends to form relations with himself, and the outer world around him, and to make every possible effort in any work he does, and therefore believes in his efficiency and ability to affect the events around him, and redirect them towards his own advantage. He considers the problems, the stressful events and the changes as something normal that lead to the development of his personality. This in general represents the psychological hardiness. The researches of (Al Abdali, 
2012); (Berada et al, 2015); (Jamal, 2017); (Ash'ash ،2018) show that there is a positive relationship between psychological hardiness and problem confrontation, and overcoming them by solving problems instead of denying or avoiding them. This is due to that the lower the psychological hardness of the individual, the less he has to use the correct facing methods that help him to face the stress. While a study (Auten, 1990) found no relationship between ego strength or psychological hardiness and the planning to solve problems. Another study (Awali, 2016) found that there is a negative relationship between psychological hardiness and stress perception.

Actually, the researcher chose this particular research based on the contradictory results of previous studies, and based on his field vision and his faith in working on psychological aspects of displaced adolescents and supporting them. By focusing on positive personality differences, and the leading life closer to the source of health and motivating positive adaptation from reviving false hopes.

Therefore, highlighting the relation between psychological hardiness and ways of confronting psychological stress that leads to better understanding and development of factors that affect mental health. Furthermore, the results of this research are likely to be a starting point for designing the activities and training courses that can enrich the ability of the displaced adolescents by providing them with effective approaches to solve their problems. Based on the above, the study was determined by the following question. "What is the relationship between the ways of confronting psychological stresses and psychological hardiness of the Internally Displaced Persons of sample members?"

\section{The following sub-questions derived from the main question:}

1. Is there a relation between the ways of confronting psychological stresses and psychological hardiness?

2. Are there differences between ways of confronting psychological stress and psychological hardiness according to gender or number of years in displacement?

\section{Significance of the Study:}

1. The importance of this study stems from lack of Arabic researches that dealt with the ways of confronting stress and psychological hardiness among the displaced categories. Moreover, the rareness of local research, which dealt with the relationship between the ways of confronting stress and psychological hardiness among the group of, displaced adolescents, as far as the researcher knows.

2. The current research may contribute to give important denotations about the point at which the training and guidance programmers should 
take as a start. Through realizing stresses that the displaced are facing, the ways they are confronting them and their psychological hardiness.

3. The results of the research provides a database to develop guiding programmers and workshops to clarify the role of psychological hardiness in human life generally and in afflicted human life particularly.

4. The results of this research is the starting point for designing the activities and training courses, which can enrich the ability of the displaced adolescents by providing them with effective approaches to solve problems.

\section{Study Objectives:}

1. Determine the relationship between ways of confronting psychological stress and psychological hardiness.

2. Detect ways of confronting psychological stress and psychological hardiness in the study sample through gender and number of displaced years.

\section{Participant \\ Population:}

The study population consisted of internally displaced adolescents in Sweida's secondary schools. The study included four secondary schools (Shakib Arslan, Essam Harb, Toufic Mezher, Kamal Obaid).Their ages ranged from 15 to 18 years in the 2017/2018 academic year.

The sample population consisted of (1200) displaced according to the statistics of the education directorate.

\section{Description of the Sample:}

(A) Exploratory Sample: As a first step, an exploratory accidental sampling method was chosen to check the psychometric features of the scale. This sample included 25 displaced (10 males and 15 females) from the original study population. They were students in Sweida secondary schools (Shakib Arslan, Toufic Mezher).

(B) Main sample: The main sample was selected randomly from the original study population. The sample of the final study consisted of (200) displaced adolescents (99 males and 101 females) from Sweida secondary schools.

\section{Sampling Procedure:}

Multiple stage sampling was in the selection of participants. Firstly, specify secondary schools in As-Suwayda containing displaced adolescents (Shakib Arslan, Essam Harb, Toufic Mezher, Kamal Obaid). Secondly, 
obtaining a list of displaced student's names. Their ages ranged from 15 to 18 years. Thirdly, the researcher distributed 230 copies of the questionnaire, but only 200, were validly filled in and returned. (99), males and (101) females. Hence, the data analyzed in this chapter, was based on the 200 questionnaires retrieved.

\section{Limitation of The Study:}

The limitations of the study include the timeframe used for its implementation in 2018, the predictive ability of the tools used, and the effectiveness of the statistical methods used to answer the research questions.

\section{Methodology}

The methodology used in this study was the correlative descriptive technique.

\section{Terminology}

Ways of confronting psychological stress: Ways of confronting psychological stress in general is the individual efforts to control, reduce or tolerate internal and external demands, that caused by stressful events (Joudy, 2004). As for the procedural definition the degree obtained by sample members on the scale of ways of confronting psychological stress.

Psychological hardiness according to Kobasa (1979), is described as a general belief of the individual in his ability and effectiveness to use all available psychosocial resources in order to be able to understand, explain and effectively cope with stressful life events.

The procedural definition is the level achieved by the examinees on the scale of Psychological hardiness used in the current study.

\section{Tools:}

In this study, the researcher used the following two tools:

\section{Ways of confronting psychological stresses scale:}

The Arabic scale of ways of confronting psychological stress, (A1Abdullah, 2014). Available in Arabic versions. The scale consists of 82 clauses. The scale applies to sample of adolescents and adults totaled 100 from Syria. The Cranach's alpha coefficient reached 0.83 , while the internal consistency reached $0.74-0.53$, which was acceptable stability coefficient.

The scale consists of (82) items, all of which are phrased in a positive manner. It includes seven methods to deal with psychological stress of displaced adolescents. These are:

Planning to solve problems, seeking to find social support method, positive thinking method, focus on emotions method, denial method, negative confronting method and positive confronting method. 
The answer to each clause of the scale should be selected from (4) alternatives. Every alternative reflects the usage degree to each method in dealing with the stress. Of course, as estimated by the adolescent himself. (1I do not use this method at all. 2- I use it to some extent. 3- I sometimes use it. 4- I always use it). The answers are corrected by giving them numerical values $(1-2$ - 3 - 4).

\section{Psychological Hardiness Scale:}

The Arabic Scale of Psychological Hardiness Scale by (Nasser, 2012) is available in Arabic versions. The scale consists of 29 items distributed to the following dimensions: Commitment, control, challenge. The scale contains negative and positive phrases, and measure on a scale of five points.

Positive phrases: 1-2-3-4-5-6-7-8-9-10-11-12-13-14-15-16-18-20-2122-23-24-25-26.

The answers are corrected by giving them numerical values (5- 4- 3- 2-1).

Negative phrases: 17-19-27-28-29.

The answers are corrected by giving them numerical values (1 - 2 - 3 - 4- 5).

\section{Psychometric Properties of the Scale}

To verify the psychometric properties of the scale, the researchers assessed its validity and stability.

\section{Validity}

\section{Face Validity:}

The scale was presented to a group of specialists in psychological counseling, psychology for measurement and evaluation at the University of Damascus. The arbitrators were asked to express their opinions and observations concerning the appropriateness of the items and their usefulness with respect to the purpose of the scale. With Their opinions regarding, the clarity of the language of each item of the scale, to make comments and suggestions.

\section{Internal Validity:}

The researcher calculated the internal consistency of the scale by applying it to a survey sample consisting of (25) male and female displaced to determine the extent to which the items of the scale were consistent with each other. By calculating correlation between the dimensions of the psychological hardiness scale. The correlation between dimensions of the psychological hardiness scale ranged between 0.406 and 0.741 , which is significant at the level of 0.01 . Moreover, the correlation between the dimensions of psychological hardiness scale and total ranged between 0.776 and 0.908 . This means good internal consistency of the scale. 


\section{Stability:}

The researcher applied the scale at two different periods, separated by two weeks, for a sample of 25 displaced from outside the study sample. The calculation of the correlation coefficient between the degrees of application resulted in a correlation of 0.833 , which was a function at the level of 0.01 . In addition, the coefficient of the stability of alpha was calculated and resulted in 0.881 , which was a good stability indicator, and fit the purposes of the study.

Based on the above, it was found that the scale of psychological hardiness is good and valid for use.

The researcher applied two scales during the period between 20/10/2017 and 20/3/2018.

\section{Results and Discussion:}

To answer the research questions, mathematical means and standard deviations, the Pearson correlation coefficient, a t-test and a one-way ANOVA were used.

\section{First Question:}

Is there a relation between the ways of confronting psychological stress and psychological hardiness?

Pearson revealed that the correlation between the ways of confronting stress and psychological hardiness is a positive correlation and Significance $\left(0.195^{\star *}\right)$ at a $<0.05$. As seen in Table 1 .

Table (1) Correlation between ways of confronting Psychological stress and the psychological hardiness.

\begin{tabular}{|c|c|c|c|c|c|}
\hline Scale & N & Mean & Std. & $\begin{array}{c}\text { Pearson } \\
\text { Correlation }\end{array}$ & $\begin{array}{c}\text { Sign if. } \\
\text { Level }\end{array}$ \\
\hline Ways of confronting Psychological & 200 & 216.86 & 12.20 & \multirow{2}{*}{0.195} & \multirow{2}{*}{$0.006^{\star *}$} \\
\cline { 1 - 4 } Psychological Hardiness & 200 & 107.09 & 10.94 & & \\
\hline
\end{tabular}

Gender Differences: Table 1, illustrates the statistical averages and standard deviations for the level of ways of confronting psychological stress and psychological hardiness according to the gender variable (male, female) and the $\mathrm{t}$-test.

The $\mathrm{t}$-test indicates significant differences between males and females in the denial ways. The difference is in favor of females. As follows:

(D. of freedom $=198, T=-2.124, \mathrm{p}=0.035$ ).

The $t$-test indicates no significant differences between males and females in the ways of confronting stress and psychological hardiness based on the variable of sex. As following: (D. of freedom $=198, T=0.612, p=$ $0.541)(\mathrm{D}$. of freedom $=198, \mathrm{~T}=-0.512, \mathrm{p}=0.609)$. As seen in Table 1 . 
Table (2) The $t$-test for the level of ways of confronting psychological stresses and psychological hardiness based on the variable of sex.

\begin{tabular}{|c|c|c|c|c|c|c|c|c|}
\hline Scale & Sex & $\mathbf{N}$ & Mean & Std. & $\begin{array}{c}\text { D. of } \\
\text { freedom }\end{array}$ & $\mathbf{T}$ & $\begin{array}{c}\text { Sign if. } \\
\text { Level }\end{array}$ & \\
\hline $\begin{array}{c}\text { Planning to } \\
\text { solve problems }\end{array}$ & $\begin{array}{l}\mathrm{M} \\
\mathrm{F}\end{array}$ & $\begin{array}{c}99 \\
101\end{array}$ & $\begin{array}{l}50.94 \\
49.99\end{array}$ & $\begin{array}{l}4.25 \\
4.29\end{array}$ & 198 & 1.58 & 0.11 & no differences \\
\hline Social support & $\begin{array}{l}\mathrm{M} \\
\mathrm{F}\end{array}$ & $\begin{array}{c}99 \\
101\end{array}$ & $\begin{array}{l}37.06 \\
36.86\end{array}$ & $\begin{array}{l}5.58 \\
4.70 \\
\end{array}$ & 198 & .27 & 0.78 & no differences \\
\hline $\begin{array}{l}\text { Positive } \\
\text { thinking }\end{array}$ & $\begin{array}{l}\mathrm{M} \\
\mathrm{F}\end{array}$ & $\begin{array}{c}99 \\
101\end{array}$ & $\begin{array}{l}18.84 \\
18.81\end{array}$ & $\begin{array}{l}2.35 \\
2.49\end{array}$ & 198 & .10 & 0.91 & no differences \\
\hline $\begin{array}{l}\text { Focus on } \\
\text { emotions }\end{array}$ & $\begin{array}{l}\mathrm{M} \\
\mathrm{F}\end{array}$ & $\begin{array}{c}99 \\
101 \\
\end{array}$ & $\begin{array}{l}35.47 \\
35.32 \\
\end{array}$ & $\begin{array}{l}4.20 \\
4.44 \\
\end{array}$ & 198 & .24 & 0.80 & no differences \\
\hline Denial & $\begin{array}{l}\mathrm{M} \\
\mathrm{F}\end{array}$ & $\begin{array}{c}99 \\
101 \\
\end{array}$ & $\begin{array}{l}26.11 \\
27.07 \\
\end{array}$ & $\begin{array}{l}3.20 \\
3.23 \\
\end{array}$ & 198 & -2.12 & 0.03 & $\begin{array}{l}\text { In favor of } \\
\text { Females }\end{array}$ \\
\hline $\begin{array}{c}\text { Negative } \\
\text { confronting }\end{array}$ & $\begin{array}{l}\mathrm{M} \\
\mathrm{F}\end{array}$ & $\begin{array}{c}99 \\
101\end{array}$ & $\begin{array}{l}43.27 \\
42.73\end{array}$ & $\begin{array}{l}3.80 \\
3.74\end{array}$ & 198 & 1.01 & 0.31 & no differences \\
\hline $\begin{array}{c}\text { Positive } \\
\text { confronting }\end{array}$ & $\begin{array}{c}\mathrm{M} \\
\mathrm{F}\end{array}$ & $\begin{array}{c}99 \\
101 \\
\end{array}$ & $\begin{array}{l}24.52 \\
24.34 \\
\end{array}$ & $\begin{array}{l}5.02 \\
4.50 \\
\end{array}$ & 198 & .26 & 0.79 & no differences \\
\hline $\begin{array}{c}\text { Ways of } \\
\text { confronting } \\
\text { psychological }\end{array}$ & $\begin{array}{l}\mathrm{M} \\
\mathrm{F}\end{array}$ & $\begin{array}{c}99 \\
101\end{array}$ & $\begin{array}{l}217.39 \\
216.33\end{array}$ & $\begin{array}{l}12.06 \\
12.37\end{array}$ & 198 & 0.61 & 0.54 & no differences \\
\hline Commitment & $\begin{array}{l}\mathrm{M} \\
\mathrm{F}\end{array}$ & $\begin{array}{c}99 \\
101\end{array}$ & $\begin{array}{l}39.41 \\
39.49\end{array}$ & $\begin{array}{l}6.90 \\
7.40\end{array}$ & 198 & -0.08 & 0.93 & no differences \\
\hline Control & $\begin{array}{c}\mathrm{M} \\
\mathrm{F}\end{array}$ & $\begin{array}{c}99 \\
101\end{array}$ & $\begin{array}{l}32.96 \\
33.40\end{array}$ & $\begin{array}{l}4.04 \\
3.93\end{array}$ & 198 & -0.77 & 0.44 & no differences \\
\hline Challenge & $\begin{array}{l}\mathrm{M} \\
\mathrm{F}\end{array}$ & $\begin{array}{c}99 \\
101\end{array}$ & $\begin{array}{l}34.18 \\
34.70 \\
\end{array}$ & $\begin{array}{l}7.57 \\
6.78 \\
\end{array}$ & 198 & -0.67 & 0.50 & no differences \\
\hline $\begin{array}{c}\text { Psychological } \\
\text { hardiness }\end{array}$ & $\begin{array}{l}\mathrm{M} \\
\mathrm{F}\end{array}$ & $\begin{array}{c}99 \\
101\end{array}$ & $\begin{array}{l}106.56 \\
107.60\end{array}$ & $\begin{array}{l}11.47 \\
10.43\end{array}$ & 198 & -0.51 & 0.60 & no differences \\
\hline
\end{tabular}

Table (3) Mathematical means and standard deviations for the level of ways of confronting stresses and Psychological hardiness according to the variable of displacement year's

number.

\begin{tabular}{|c|c|c|c|c|}
\hline Scale & $\begin{array}{c}\text { Years Differences } \\
\text { of displacement }\end{array}$ & $\mathbf{N}$ & Mean & Std. Deviation \\
\hline Planning to solve problems & $1-2$ & 46 & 47.86 & 3.90 \\
\hline & $3-4$ & 63 & 50.19 & 3.65 \\
\hline & 5 years and above & 91 & 51.96 & 4.25 \\
\hline Social support & $1-2$ & 46 & 37.41 & 4.97 \\
\hline & $3-4$ & 63 & 36.76 & 5.41 \\
\hline & 5 years and above & 91 & 36.86 & 5.08 \\
\hline Positive thinking & $1-2$ & 46 & 18.43 & 2.22 \\
\hline & $3-4$ & 63 & 19.38 & 2.18 \\
\hline & 5 years and above & 91 & 18.64 & 2.61 \\
\hline & $1-2$ & 46 & 34.41 & 4.35 \\
\hline Focus on emotions & $3-4$ & 63 & 35.41 & 4.24 \\
\hline & 5 years and above & 91 & 35.89 & 4.31 \\
\hline
\end{tabular}




\begin{tabular}{|c|c|c|c|c|}
\hline Denial & $1-2$ & 46 & 26.84 & 3.06 \\
\hline & $3-4$ & 63 & 26.11 & 2.91 \\
\hline & 5 years and above & 91 & 26.81 & 3.54 \\
\hline \multirow[t]{3}{*}{ Negative confronting } & $1-2$ & 46 & 43.34 & 3.57 \\
\hline & $3-4$ & 63 & 42.53 & 3.84 \\
\hline & 5 years and above & 91 & 43.14 & 3.84 \\
\hline \multirow[t]{3}{*}{ Positive confronting } & $1-2$ & 46 & 24.34 & 4.22 \\
\hline & $3-4$ & 63 & 23.88 & 4.65 \\
\hline & 5 years and above & 91 & 24.85 & 5.08 \\
\hline \multirow[t]{3}{*}{$\begin{array}{c}\text { Ways of confronting } \\
\text { psychological }\end{array}$} & $1-2$ & 46 & 214.23 & 10.10 \\
\hline & $3-4$ & 63 & 214.90 & 11.21 \\
\hline & 5 years and above & 91 & 219.53 & 13.34 \\
\hline \multirow[t]{3}{*}{ Commitment } & $1-2$ & 46 & 40.23 & 6.422 \\
\hline & $3-4$ & 63 & 40.66 & 5.96 \\
\hline & 5 years and above & 91 & 38.21 & 8.045 \\
\hline \multirow[t]{3}{*}{ Control } & $1-2$ & 46 & 32.60 & 4.39 \\
\hline & $3-4$ & 63 & 33.15 & 3.92 \\
\hline & 5 years and above & 91 & 33.50 & 3.82 \\
\hline \multirow[t]{3}{*}{ Challenge } & $1-2$ & 46 & 34.23 & 7.33 \\
\hline & $3-4$ & 63 & 34.28 & 7.49 \\
\hline & 5 years and above & 91 & 34.65 & 6.93 \\
\hline \multirow[t]{3}{*}{ Psychological hardiness } & $1-2$ & 46 & 107.08 & 11.21 \\
\hline & $3-4$ & 63 & 108.11 & 10.29 \\
\hline & 5 years and above & 91 & 106.38 & 11.30 \\
\hline
\end{tabular}

A one-way ANOVA analysis of the data revealed no significant differences in the level of psychological hardiness in the sample with respect to the variable of displacement year's number. This indicates that the levels of psychological hardiness in the sample are similar despite Years Differences of displacement. As following:( $\mathrm{F}=0.461, \mathrm{P}=0.632)$.

A one-way ANOVA analysis of the data revealed are significant differences in the level of Ways of confronting Psychological stress in the sample with respect to the variable of displacement year's number. This indicates that the ways of confronting Psychological stress in the sample are based on the variable in the number of years of displacement. As follows: ( $\mathrm{F}=$ 4.194, $\mathrm{P}=0.016$ ). As seen in Table 3. 
Table (4) One-Way ANOVA analysis for the level of ways of confronting Psychological stresses and Psychological hardiness according to the variable of displacement year's number.

\begin{tabular}{|c|c|c|c|c|c|c|}
\hline Scale & Source of Difference & $\begin{array}{l}\text { Total of } \\
\text { Squares }\end{array}$ & $\begin{array}{c}\text { D. of } \\
\text { freedom }\end{array}$ & $\begin{array}{l}\text { Mean of } \\
\text { Squares }\end{array}$ & $\mathbf{F}$ & $\begin{array}{c}\text { Sign if. } \\
\text { Level }\end{array}$ \\
\hline \multirow[t]{3}{*}{$\begin{array}{c}\begin{array}{c}\text { Planning to solve } \\
\text { problems }\end{array} \\
\end{array}$} & Between Groups & 519.92 & 2 & 259.96 & 16.26 & 0.000 \\
\hline & Inside Groups & 3147.83 & 197 & 15.97 & & \\
\hline & Grand total & 3667.75 & 199 & & & \\
\hline \multirow[t]{3}{*}{ Social support } & Between Groups & 12.68 & 2 & 6.34 & 0.23 & 0.789 \\
\hline & Inside Groups & 5264.99 & 197 & 26.72 & & \\
\hline & Grand total & 5277.68 & 199 & & & \\
\hline \multirow[t]{3}{*}{ Positive thinking } & Between Groups & 29.31 & 2 & 14.65 & 2.54 & 0.081 \\
\hline & Inside Groups & 1134.90 & 197 & 5.76 & & \\
\hline & Grand total & 1164.22 & 199 & & & \\
\hline \multirow[t]{3}{*}{ Focus on emotions } & Between Groups & 66.67 & 2 & 33.33 & 1.80 & 0.168 \\
\hline & Inside Groups & 3643.32 & 197 & 18.49 & & \\
\hline & Grand total & 3710.00 & 199 & & & \\
\hline \multirow[t]{3}{*}{ Denial } & Between Groups & 22.01 & 2 & 11.00 & 1.04 & 0.355 \\
\hline & Inside Groups & 2081.98 & 197 & 10.56 & & \\
\hline & Grand total & 2104.00 & 199 & & & \\
\hline \multirow[t]{3}{*}{$\begin{array}{c}\text { Negative } \\
\text { confronting }\end{array}$} & Between Groups & 20.77 & 2 & 10.38 & 0.72 & 0.485 \\
\hline & Inside Groups & 2819.22 & 197 & 14.31 & & \\
\hline & Grand total & 2840.00 & 199 & & & \\
\hline \multirow[t]{3}{*}{$\begin{array}{c}\text { Positive } \\
\text { confronting }\end{array}$} & Between Groups & 35.35 & 2 & 17.67 & 0.77 & 0.461 \\
\hline & Inside Groups & 4475.80 & 197 & 22.72 & & \\
\hline & Grand total & 4511.15 & 199 & & & \\
\hline \multirow[t]{3}{*}{$\begin{array}{c}\text { Ways of } \\
\text { confronting } \\
\text { Psychological } \\
\text { stresses } \\
\end{array}$} & Between Groups & 1209.66 & 2 & 604.83 & 4.19 & 0.016 \\
\hline & Inside Groups & 28412.41 & 197 & 144.22 & & \\
\hline & Grand total & 29622.08 & 199 & & & \\
\hline \multirow[t]{3}{*}{ Commitment } & Between Groups & 259.62 & 2 & 129.81 & 2.58 & .078 \\
\hline & Inside Groups & 9887.97 & 197 & 50.19 & & \\
\hline & Grand total & 10147.59 & 199 & & & \\
\hline \multirow[t]{3}{*}{ Control } & Between Groups & 24.66 & 2 & 12.33 & 0.77 & 0.462 \\
\hline & Inside Groups & 3138.11 & 197 & 15.93 & & \\
\hline & Grand total & 3162.78 & 199 & & & \\
\hline \multirow[t]{2}{*}{ Challenge } & Between Groups & 7.72 & 2 & 3.86 & 0.07 & 0.928 \\
\hline & Inside Groups & 10229.66 & 197 & 51.92 & & \\
\hline
\end{tabular}




\begin{tabular}{|c|c|c|c|c|c|c|}
\hline & Grand total & 10237.39 & 199 & & & \\
\hline $\begin{array}{c}\text { Psychological } \\
\text { hardiness }\end{array}$ & Between Groups & 110.96 & 2 & 55.48 & 0.46 & 0.632 \\
\hline & Inside Groups & 23735.41 & 197 & 120.48 & & \\
\hline & Grand total & 23846.38 & 199 & & & \\
\hline
\end{tabular}

In order to identify the amount of these differences between groups, the researcher used Test of the Multiple Comparisons Dunnett C:

The differences between the categories of the displacement years number according to the planning style to solve problems are statistically significant across categories (1-2, 3-4, 5 years and above). The category 5 years and above achieved a higher degree of the planning to solve problems.

The differences between the categories of the displacement years number in the ways of confronting Psychological stresses are statistically significant across categories (1-2, 5 years and above). The category 5 years and above achieved a higher degree of Ways of confronting Psychological stresses.

\section{Discussions}

In light of the above this study aimed to identify the relationship between ways of confronting stresses and psychological hardiness. To clarify the extent of gender differences in the used ways of confronting stresses. This study found that the number of years in displacement and gender Play a role as mediating factors of the relation between Ways of Confronting Psychological Stresses and Psychological Hardiness.

The results are generally not conclusive in this context and will vary according to the sample and its characteristics (Arafi, 2014); (Al Abdalla, 2014). (Al Zayoud, 2014). Their cope with pressures and dealing with them depend on categories of age they belong to, also depend on the characteristics and psychological attributes they have. This was what the study of (Petrie and Rotheram, 1982) confirmed about insulators and barriers against psychological stress such as; self-esteem and tendency to assertiveness. Kobasa concluded that as stress increases, so does the beneficial effect of Hardiness. Hardiness is described as a buffer against the effects of stressful life events (Kobasa,1982); (Reinhoudt \& Cynthia, 2004); (Kobasa et al, 1982). The results of the study (Ash'ash, 2018) showed that there is a positive correlation between the students' scores on both the measure of facing methods and the scale of psychological hardness. Whenever a student got a low score on the psychological hardness scale got a low score also on the methods of facing scale. This is due to that the lower the psychological hardness of the individual, the less he has to use the correct facing methods that help him to face the stress. 
While the results of this study showed no differences between males and females in psychological hardiness. This result is consistent with the results of (Soderstrom, 2000); (Nasser, 2012); (Al Mishaan, 2011), while is inconsistent with the study results of (Kafa, 2012); (Yaprak ,Güçlü, Durhan, 2018).

As for the results which showed that there are no statistically significant differences in the psychological hardiness based on sex variable, it is likely can be the reason for this is the convergence of responsibilities and stress imposed by everyday life, displacement, stressful life events.

As for the results, which showed that there are no differences in psychological hardiness based on the variables of number of displacement years, it may be because this variable may not play a role in the features of coping and challenge possessed by the individuals. However, individual psychology and potentials play the most important role.

As for the results which showed that there are no statistically significant differences in the ways of confronting stress based on sex variable, except for the denial method, which is significant and the difference is in favor of females. We can say that females are more inclined to ignore their problems and to daydream, while at the same time less inclined to use direct confrontation. Therefore, they preferred the method of denying or ignoring stresses. While, the results of study showed, (Labd, 2013) no differences between males and females in the method of denying or ignoring stress. And The presence of statistically significant differences in the dimensions of positive reinterpretation and growth, focusing on and venting of emotions, Seeking social support, active coping, turning to religion, and planning, according to the sex, in favor to the female of the sample. The study of (Kumar \& Ramamourt 1990) showed that females are more inclined to use strategies for logical analysis, counseling obtain than males, and males are more inclined to use strategies for logical reassessment strategy than females.

Finally, the study found differences in the ways of confronting stress based on the variable of displacement years. The differences in the planning style to solve problems according to displacement year's number. The category (5 years and above) a higher degree of the planning to solve problems. This result is logical as it relates to everyday life expertise, ability to learn from experiences and realizing the sources of stress more over time; than reaching the appropriate ways of confrontation. In addition, the participation of IDPs in counseling and psychological support courses over time, has contributed to developing some ways of confronting stress and problems. This result is consistent with confirmed by (Lazarus and Folkman, 1988); that stressresistant individuals who are capable influencing their environment, are more often to use active and effective confronting ways as a response to problem 
solving. Therefore, psychological hardiness connects positively in planning to solve problems method, social support method and positive coping method.

The results of this research are starting point for designing the activities and training courses, which can enrich the ability of the displaced adolescents by providing them with effective approaches to solve problems.

\section{Recommendations and Future Research Directions}

1. Researchers should focus on the importance of psychological hardiness development programs, workshops and training courses for displaced adolescents. As well as, mental health practitioners should focus on the planning of integrated rehabilitation programs; also, they should pay attention to social support and family unity. Further study of the ways of confronting stresses.

2. Conduct future research, which includes new variables such as the psychological resilience, health, and use statistical methods such as linear regression.

\section{Acknowledgements}

The author thank all the staff and students displaced at Sweida secondary schools (Shakib Arslan, Toufic Mezher) for their help and support in the undertaking of this project, without them this project could not have been completed.

\section{Funding}

The author have not declared a specific grant for this research from any funding agency in the public, commercial or not-for-profit sectors. The opinions or views expressed are those of the author.

\section{Competing interests}

None declared.

\section{Patient consent for publication}

Not required.

\section{References:}

1. Abbass, A. (2006). The Methods Confront Psychological Trauma and its Relationship with Backstopping Family in Adolescents living in Shelters in the city of Damascus. Damascus university, Syrian Arab Republic: Unpublished MA thesis. Retrieved 5 3, 2015, from http://mohe.gov.sy/master/Message/Mc/abir\%20abas.pdf.

2. Al Abdali, KH. (2012). Psychological hardiness and its relation to the ways of confronting psychological stresses among a sample of high 
school outstanding and normal students in the holy city of Mecca. Umm Al Qura University, kingdom of Saudi Arabia: Unpublished MA thesis. http://www.uqu.edu.sa/page/ar/583

3. Al Abdalla, F.(2014). Methods of dealing with psychological stresses and their relation to parental treatment methods among adolescents in the secondary schools of Damascus City. Damascus university, Syrian Arab Republic: Unpublished PhD thesis. http://mohe.gov.sy/Masters/Message/PH/faiza\%20alabdalla.pdf.

4. Al Mishaan, O. S (2011). The relation of psychological hardiness with physical complaints, hope and happiness among employees of both sexes in the public sector. Journal of Social Sciences, 39 (3), 49-81. pubcouncil.kuniv.edu.kw/jss/homear.aspx?id=8\&Root=yes

5. Al Safadi, R.(2013). Social support, psychological hardiness and their relation to the future concern of wives of martyrs and widows in Gaza. Al-Azhar University, Palestine: Unpublished MA thesis. https://iugspace.iugaza.edu.ps/handle/20.500.12358/16527

6. Al Sherbini, H. (2005). The trend toward academic fraud and its relation to psychological hardiness and feeling guilty among a sample of university students. Journal of Faculty of Education in Al Mansoura, 2(59), 347-382.

7. Al Zayoud, N.(October 2014,2). Ways of dealing with psychological stresses among Qatar University students and their relation to some variables. Journal of the Message of the Arabian Gulf, 99, 1-55. Retrieved from www.acofps.com/vb/attachment.php?attachmentid

8. Arafi, A. (2014). Ways of confronting stresses and their relation to self-assertion (among high school students in the governorate of Mahd al-Zahab). Umm Al Qura University, kingdom of Saudi Arabia: Unpublished MA thesis.

9. Ash'ash, N. M. H . (2018). Ways of Confronting Psychological Stresses and its Relation to Psychological Hardiness among university students. Journal of the Faculty of Education, Port Said University , 23, 401-430 doi:10.21608/JFTP.2018.32175

10. Berada, A., Constance, K., Al Shami, R., Deville, J,. Yousef, A,. Jivy, H,. Berkil, A,. Kots, A,.\& Song, S. (2015). Culture, mental health and well-being of Syrians. A review of mental health and psychosocial support for staff working with Syrians affected by armed conflict. Published by UNHCR, Advance online publication. Retrieved from https://data2.unhcr.org/en/documents/details/44027.

11. Fedman, N. (2010). Psychosocial Support Guide based on local community. Damascus. Paramedia.

12. Ghalyanee, B. (2016). Relationship between Self-Esteem and Psychological Hardiness in Adolescents: A Relation Design. The 
International Journal of Indian Psychology, 10(3), 116- 122. DIP: 18.01.185/20160303.

13. Hasanvand, B., Khaledian, M., \& Merati, A. R. (2013). The relationship between psychological hardiness and attachment styles with the university student's creativity. European Journal of Experimental Biology, 3(3), 656-660. www.pelagiaresearchlibrary.com.

14. Hashemi, S.H., Ahadi, H., \& Yekta, M.A. (2017). Relationship between psychological hardiness and self-efficacy in patients with type 2 diabetes: (The mediating role of self-esteem and social support) using structural equation modeling. European Online Journal of Natural and Social Sciences, 6(2), 273-287. www.europeanscience.com.

15. Hijazi, J. \& Abu Ghali, A. (2010). Problems of the elderly (aging) and their relation to psychological hardiness."A Field Study on a Sample of Palestinian Elderly in Gaza Governorates. Journal for Research Humanities, 24 (1), 109- 156.

16. International Law Series No. 8.(2008). Internally Displaced Persons (IDPs) "in International Humanitarian Law. Retrieved from https://mezan.org/uploads/files/8797.pdf

17. Jamal, Y. (2017). Coping Strategies as a Mediator of Hardiness and Stress among Rescue Workers. Journal Studies on Ethno-Medicine, 11(3), 201-208. https://doi.org/10.1080/09735070.2017.1356033.

18. Jindal, K. (2013). effect of hardiness and social support on satisfaction with life and happiness in retired engineers. International Journal of Advanced Research in Management and Social Sciences, 12(2). www.garph.co.uk.

19. Joudy, A. (2004). Ways of confronting stressful life events and their relation to mental health in a sample of Al-Aqsa University students. Research presented to the first educational conference. Education in Palestine and the changes in the current era held in the Faculty of Education, Islamic University, in 23-24 /11/ 2004.

20. Kafa, R. (2012). Psychological hardiness and its relation to social support among elderly persons - A field study on a sample of elderly in social care homes. Damascus University, Syrian Arab Republic: Unpublished Master thesis.

21. Khalil, A. \& Abdullah., Aisha A. (2013). Ways of confronting psychological stresses among patients with renal failure in the kidney wash centers in El Fasher and Nyala. Um durman Islamic Journal, 3. June, 41-81. 
22. Kobasa, S.C.(1982). Commitment and coping in stress resistance among lawyers. Journal of Personality and Social Psychology, 45(4), 707-717. http://dx.doi.org/10.1037/0022-3514.42.4.707

23. Kobasa, S.C., Maddi, S.R., \& Kahn, S.(1982). Hardiness and health: A prospective study. Journal of Personality and Social Psychology, 42(1), 168-177.doi: 10.1037/0022-3514.42.1.168.

24. Lebd, M. (2013). Coping strategies of Life Stress and Their Relationship to Psychological Adjustment Among Students of Middle Community Colleges In the Gaza Strip. Alazhar University of Gaza, Palestine: Unpublished MA thesis. www.alazhar.edu.ps/Library/aattachedFile.asp?id_no=0046401

25. Mohammed, A. (2017). Ways of confronting psychological stresses between returning and non-returning students from displacement. Journal of the Professor. issue of the Fifth Scientific Conference.3760. https://search.emarefa.net/detail/BIM-790970.

26. Nasser, O. D., (2012). The Strategies of confrontation work problems and their relationship with the psychological hardiness and the job security, A field study of the management levels (upper, middle, executive) in the directorates and the state establishments of Swaida. Damascus university, Syrian Arab Republic: Unpublished PHD thesis.

27. Patel, V. (2008). Mental Health for All Book - No Psychiatrist (Addition.1).Published by Beirut: Arab Resource Workshop.

28. Radi, Z. (2008). The psychological hardiness of the mothers of martyrs of Al-Aqsa Intifada and its relation to some variables. Islamic University of Gaza, Palestine: Unpublished MA thesis. https://iugspace.iugaza.edu.ps/handle/20.500.12358/21284?localeattribute $=$ en

29. Radwan, S.(2007). Mental Health (Addition. 2),Published by Amman: Dar Al Masirah.

30. Reinhoudt, M.A. \& Cynthia, J. (2004). Factors Related to Aging Well: The Influence of Optimism, Hardiness And Spiritual Well Being On The Physical Health Functioning Of Older Adults. The Ohio State University, USA: Unpublished PHD thesis. https://etd.ohiolink.edu/!etd.send_file?accession=osu1092771722.

31. Shalhoub, D.J., (2016). Future anxiety and its relationship With Psychological Hardiness, A field study on a sample of youth in the provisional asylum centres in Damascus and Sawida cities. Damascus university, Syrian Arab Republic: Unpublished MA thesis.

32. Soderstrom, M., Dolbier, Ch., Leiferman, J., \& Steinhardt, M. (2000). The Relationship of Hardiness, Coping Strategies, and Perceived Stress to Symptoms of Illness. Journal of Behavioral Medicine, 23(3), 311-328. http://dx.doi.org/10.1023/A:1005514310142. 
33. Yaprak, P., Güçlü, M., \& Durhan,T. (2018). The Happiness, Hardiness, and Humor Styles of Students with a Bachelor's Degree in Sport Sciences. Behavioral Sciences, (82)8, 1-21. doi:10.3390/bs8090082.

Appendix (1)Psychological Hardiness Scale

\begin{tabular}{|c|c|c|c|c|c|}
\hline Phrases & Always & $\begin{array}{c}\text { Often } \\
4\end{array}$ & $\begin{array}{l}\text { Sometimes } \\
3\end{array}$ & $\begin{array}{l}\text { Rarely } \\
\quad 2\end{array}$ & $\begin{array}{c}\text { Never } \\
1\end{array}$ \\
\hline \multicolumn{6}{|l|}{ I can achieve my goals whatever the obstacles are. } \\
\hline \multicolumn{6}{|l|}{ I think my life has a meaning that I live for. } \\
\hline \multicolumn{6}{|l|}{$\begin{array}{l}\text { I have certain values and principles that I respect } \\
\text { and preserve them. }\end{array}$} \\
\hline \multicolumn{6}{|l|}{$\begin{array}{l}\text { I participate in any activity that serves the } \\
\text { community live in. }\end{array}$} \\
\hline \multicolumn{6}{|l|}{ I stand by others when they face any problem. } \\
\hline \multicolumn{6}{|l|}{$\begin{array}{l}\text { I care about the issues and events that take place } \\
\text { around me. }\end{array}$} \\
\hline \multicolumn{6}{|l|}{ Life is worthy with all its conditions. } \\
\hline \multicolumn{6}{|l|}{ I feel responsible to others and try to help them. } \\
\hline \multicolumn{6}{|l|}{$\begin{array}{l}\text { I am interested in public issues and participate in } \\
\text { them. }\end{array}$} \\
\hline \multicolumn{6}{|l|}{$\begin{array}{l}\text { I abide by laws and regulations even if it does not } \\
\text { suit me. }\end{array}$} \\
\hline \multicolumn{6}{|l|}{$\begin{array}{l}\text { I made my own decisions without the intervention } \\
\text { of others. }\end{array}$} \\
\hline \multicolumn{6}{|l|}{$\begin{array}{l}\text { My success in my life depends on my efforts } \\
\text { (work, study... etc.) not on luck or chance. }\end{array}$} \\
\hline \multicolumn{6}{|l|}{$\begin{array}{l}\text { I think failure is due to reasons that lie in the } \\
\text { person himself. }\end{array}$} \\
\hline \multicolumn{6}{|l|}{$\begin{array}{l}\text { I control my life events, so nothing happens to me } \\
\text { by chance. }\end{array}$} \\
\hline \multicolumn{6}{|l|}{ I can control the course of my life. } \\
\hline \multicolumn{6}{|l|}{ I feel able to control my destiny. } \\
\hline \multicolumn{6}{|l|}{ I think my influence is poor on events that I face. } \\
\hline \multicolumn{6}{|l|}{$\begin{array}{l}\text { I plan for my life and don't leave it to chance or } \\
\text { luck. }\end{array}$} \\
\hline \multicolumn{6}{|l|}{$\begin{array}{l}\text { The best way to cope with problems is to ignore } \\
\text { them. }\end{array}$} \\
\hline \multicolumn{6}{|l|}{$\begin{array}{l}\text { I thinkthe fun and excitement of life lies in the } \\
\text { individual's ability to meet life challenges. }\end{array}$} \\
\hline \multicolumn{6}{|l|}{$\begin{array}{l}\text { I consider hardships of life as opportunities and } \\
\text { coping with them benefits my personal } \\
\text { development. }\end{array}$} \\
\hline \multicolumn{6}{|l|}{ I think life is exciting and has problems I can face. } \\
\hline \multicolumn{6}{|l|}{ I have ability to persist till solving my problems. } \\
\hline $\begin{array}{l}\text { Problems strengthen my power and ability to } \\
\text { challenge. }\end{array}$ & & & & & \\
\hline
\end{tabular}




\begin{tabular}{|l|l|l|l|l|l|}
\hline $\begin{array}{l}\text { I think confronting problems is a test of my } \\
\text { strength and my ability to persevere. }\end{array}$ & & & & & \\
\hline $\begin{array}{l}\text { I think life that does not include changes is boring } \\
\text { and routine. }\end{array}$ & & & & & \\
\hline $\begin{array}{l}\text { I fear the changes of life; every change may } \\
\text { threaten me and my life. }\end{array}$ & & & & & \\
\hline $\begin{array}{l}\text { I feel afraid to face problems even before they } \\
\text { happen. }\end{array}$ & & & & & \\
\hline $\begin{array}{l}\text { I feel overwhelmed by what is happening in my } \\
\text { life. }\end{array}$ & & & & & \\
\hline
\end{tabular}

Appendix (2) Ways of Confronting Psychological Stresses Scale

\begin{tabular}{|c|c|c|c|c|}
\hline Statement & $\begin{array}{l}\text { I never } \\
\text { use this } \\
\text { method } \\
(4)\end{array}$ & $\begin{array}{l}\text { I use it } \\
\text { sometimes } \\
\text { (3) }\end{array}$ & $\begin{array}{l}\text { I use to } \\
\text { some extent } \\
(2)\end{array}$ & $\begin{array}{c}\text { I } \\
\text { always } \\
\text { use it } \\
(1) \\
\end{array}$ \\
\hline \multicolumn{5}{|l|}{$\begin{array}{l}\text { When I face a problem, I can't stop thinking about } \\
\text { it. }\end{array}$} \\
\hline \multicolumn{5}{|l|}{$\begin{array}{l}\text { I study the aspects of the problem to be aware of } \\
\text { the various matters related to it. }\end{array}$} \\
\hline \multicolumn{5}{|l|}{ I collect information about the problem I face. } \\
\hline \multicolumn{5}{|l|}{$\begin{array}{l}\text { I planning in my mind what I will do to solve the } \\
\text { problem. }\end{array}$} \\
\hline \multicolumn{5}{|l|}{$\begin{array}{l}\text { I concentrate my efforts on doing something to } \\
\text { solve the problem. }\end{array}$} \\
\hline \multicolumn{5}{|l|}{$\begin{array}{l}\text { I organize my time to suit the conditions of the } \\
\text { problem. }\end{array}$} \\
\hline \multicolumn{5}{|l|}{ I try to find a better way to deal with the problem. } \\
\hline \multicolumn{5}{|l|}{ I do my best to solve the problem. } \\
\hline \multicolumn{5}{|l|}{ I use all my abilities to solve the problem. } \\
\hline \multicolumn{5}{|l|}{$\begin{array}{l}\text { I plan the steps to be taken to resolve the problem } \\
\text { in details. }\end{array}$} \\
\hline \multicolumn{5}{|l|}{ I focus on what I will do next. } \\
\hline \multicolumn{5}{|l|}{ I put alternative solutions to the problem I face. } \\
\hline \multicolumn{5}{|l|}{ I follow the plan I set out to solve the problem. } \\
\hline \multicolumn{5}{|l|}{$\begin{array}{l}\text { I choose the appropriate solution of several } \\
\text { solutions to cope with the problem. }\end{array}$} \\
\hline \multicolumn{5}{|l|}{ I ask other people help to solve my problems. } \\
\hline \multicolumn{5}{|l|}{$\begin{array}{l}\text { Some of my friends help me getting rid of the } \\
\text { problems that I face. }\end{array}$} \\
\hline \multicolumn{5}{|l|}{$\begin{array}{l}\text { I think of a trusted person to help me solve the } \\
\text { problem. }\end{array}$} \\
\hline \multicolumn{5}{|l|}{$\begin{array}{l}\text { I talk to someone to help get a better } \\
\text { understanding of the problem. }\end{array}$} \\
\hline \multicolumn{5}{|l|}{$\begin{array}{l}\text { I talk to someone who can actually do something } \\
\text { practical about the problem. }\end{array}$} \\
\hline \multicolumn{5}{|l|}{$\begin{array}{l}\text { I talk to a particular person about my feelings } \\
\text { toward the problem. }\end{array}$} \\
\hline I ask for help from others for the problems I face. & & & & \\
\hline
\end{tabular}




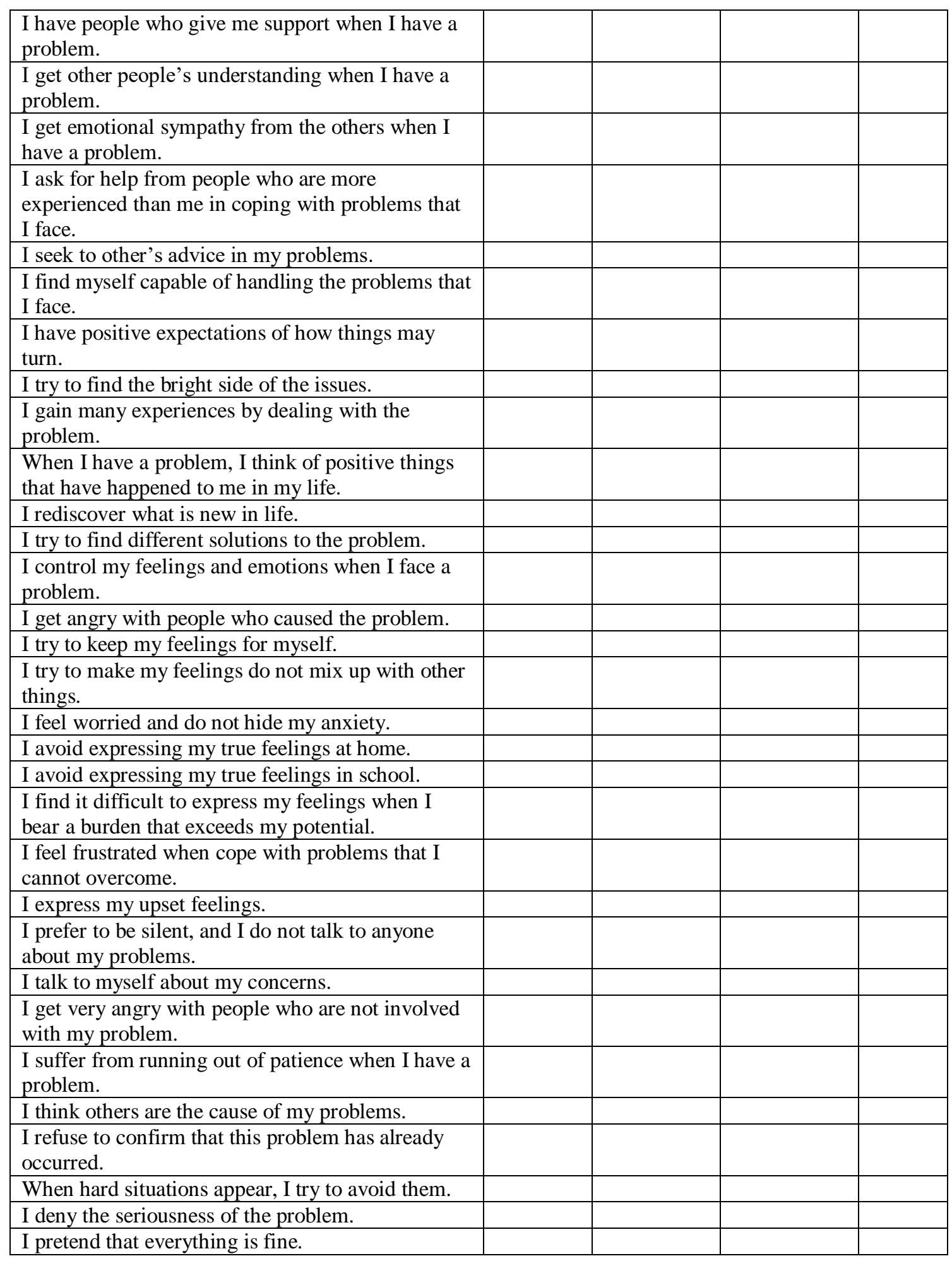




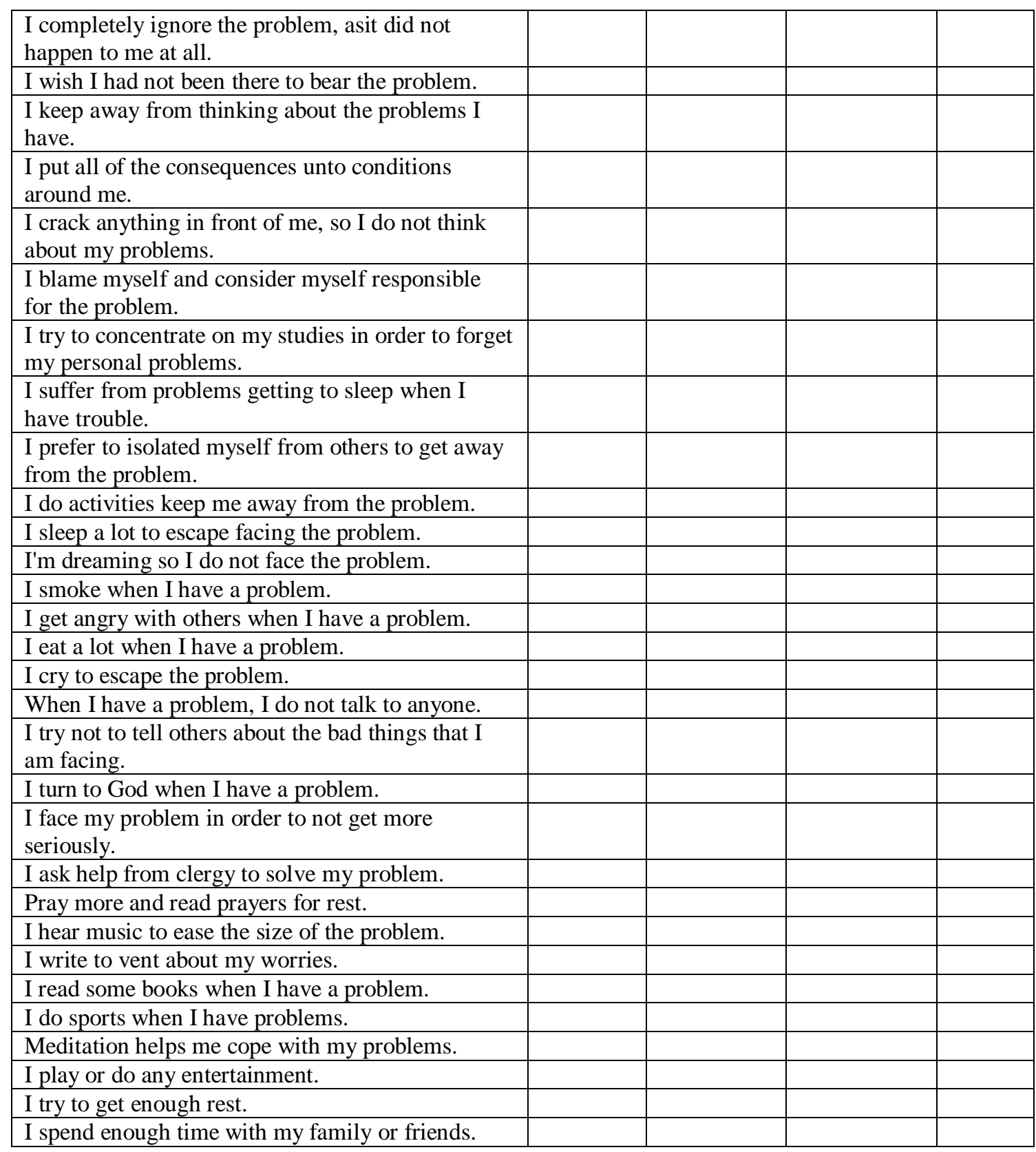

